九州大学学術情報リポジトリ

Kyushu University Institutional Repository

\title{
A New Record of a Snowbank Fungus, Mycena overholtsii, from Japan
}

Cha, Joo Young

Field Science Center for Northern Biosphere, Hokkaido University

Lee, Sang Yong

The Professional Graduate School of Disaster Prevention Technology, Kangwon National University

Chun, Kun Woo

Division of Forest Resource, Kangwon National University

Lee, Si Young

The Professional Graduate School of Disaster Prevention Technology, Kangwon National University | Division of Forest Resource, Kangwon National University

他

https://doi.org/10.5109/17804

出版情報: 九州大学大学院農学研究院紀要. 55 (1)，pp.77-78，2010-02-26. Faculty of Agriculture， Kyushu University

バージョン :

権利関係 : 


\title{
A New Record of a Snowbank Fungus, Mycena overholtsii, from Japan
}

\author{
Joo Young CHA ${ }^{1}$, Sang Yong $\mathrm{LEE}^{2 *}$, Kun Woo $\mathrm{CHUN}^{2}$, \\ Si Young $\mathrm{LEE}^{3}$ and Shoji OHGA
}

\author{
Laboratory of Forest Resources Management, Division of Forest Ecosphere Management, \\ Department of Forest and Forest Products Sciences, Kyushu University, \\ Sasaguri, Fukuoka 811-2415, Japan \\ (Received November 17, 2009 and accepted November 19, 2009)
}

\begin{abstract}
This report provides the first record of Mycena overholtsii from Japan, and macro- and microscopic features are described and illustrated. This species was found growing in clusters on conifer logs and stumps near melting snowbanks. It was named 'yukitsutsumikunugitake' in Japanese.
\end{abstract}

\section{INTRODUCTION}

Snowbanks linger long into spring and summer in heavily timbered areas of the high Rocky Mountains. A unique guild of macrofungi, apparently only found in western North America, occurs in close association with slowly retreating high-elevation snowbanks and their meltwaters. Mycologists have termed these fungi 'snowbank fungi' because of the constancy of their fruiting habitat. The snowbank fungi are more dependent on snowmelt than rain for their moisture. Most snowbank fungi are thought to be endemic to western North America, and have been primarily reported from the Rocky Mountain and Cascade ranges (Miller, 1965). Large Mycena species, such as a M. overholtsii A. H. Sm. \& Solheim, are a conspicuous part of the spring fungi throughout much of the western North American mountains (Smith and Solheim, 1953; Miller, 1985).

Snowbanks also form in spring and early summer in boreal coniferous forests of Hokkaido in Japan. We investigated the spring fungi near snowbanks and collected a large Mycena species. The specimens collected represent the first record of a snowbank species from Japan, and are described and illustrated here.

\section{MAREIALS AND METHODS}

The description of macroscopic features is based on fresh basidiomes. Names of colors in parentheses are taken from Munsell (1990). For microscopic features, a part of the material from dried basidiomes was cut and placed in 95\% ethanol for about $1 \mathrm{~h}$, then transferred to tap water until specimens became pliable (Miyamoto et al., 1996). Freehand sections of the rehydrated material were examined in distilled water, $5 \% \mathrm{KOH}$, and Melzer's

\footnotetext{
Field Science Center for Northern Biosphere, Hokkaido University, Nayoro 096-0071, Japan

2 Division of Forest Resource, College of Forest and Environmental Sciences, Kangwon National University, Chuncheon 200-701, Korea

3 The Professional Graduate School of Disaster Prevention Technology, Kangwon National University, Samcheok 245-711, Korea

* Corresponding author (E-mail: sangyong@kangwon.ac.kr)
}

reagent. Voucher specimens have been deposited at the herbarium of the Field Science Center for the Northern Biosphere, Hokkaido University, Japan.

\section{DESCRIPTION AND DISCUSSION}

Mycena overholtsii A. H. Sm. \& Solheim, Madrono 12: $106,1953$.

Pileus $1.4-3.5 \mathrm{~cm}$ in diameter, $0.5-2.5 \mathrm{~cm}$ high, at first broadly conic to campanulate, then convex, expanding to plano-convex, margin in some recurved with age, striate; surface glabrous, lubricous when moist, very pale brown $(10 \mathrm{YR}-8 / 3,7 / 4)$ at center, very pale brown (10YR8/2) to grayish brown (10YR-5/2) toward margin; flesh whitish; odor and taste mild; lamellae broadly adnate to slightly decurrent, close to subdistant, whitish to pale gray; stipe $5-12 \times 0.2-0.4 \mathrm{~cm}$, cylindrical, slightly enlarged at the base; surface glabrous at the apex, brown (10YR$5 / 3,4 / 3$ ) toward base, covered with a white to pale brown tomentum; stipe base fused with adjoining basidiomes; context hollow at maturity, partially absent.

Basidospores 6.3-7.5×3-3.8 $\mu \mathrm{m}$, ellipsoidal to oblong, hyaline, smooth, amyloid, white spore print; basidia clavate, $27.5-37.5 \times 5 \mu \mathrm{m}$, four-spored, with clamp connection at the base; pleurocystidia not seen; cheilocystidia filamentous to fusoid-ventricose, scattered, 35-50×2.5$5.0 \mu \mathrm{m}$, smooth; hyphae of hymenophoral trama slightly interwoven to subparallel, inflated; hyphae of pileipellis parallel and ixocutis of repent hyphae, 2.50-3.75 $\mu \mathrm{m}$ across, smooth with a few scattered simple diverticula embedded in a gelatinous matrix; hyphae of stipe parallel, smooth, with irregularly cylindric and often lobed terminal cells.

Habitat: cespitose on decaying coniferous logs and stumps, in plantations of Abies sachalinensis Masters and natural mixed A. sachalinenesis and Picea jezoensis Carr., from May; basidiomes often found on wood still partly buried in the snow.

Specimens examined: JYC289, in a plantation of $A$. sachalinensis, Mt. Sapporotake, Sapporo-si, Hokkaido, May 28, 2005; JYC200703, in natural mixed forest with A. sachalinenesis and P. jezoensis, Mt. Pangkezan, Nakagawa Experimental Forest of Hokkaido University, Nakagawa-cho, Nakagawa-gun, Hokkaido, May 16, 2007; 
JYC200901, in natural mixed forest with A. sachalinenesis and $P$. jezoensis, Mt. Pangkezan, Nakagawa Experimental Forest of Hokkaido University, Nakagawacho, Nakagawa-gun, Hokkaido, Japan, May 8, 2009. All specimens were collected by J. Y. Cha.

Japanese name: yukitsutsumikunugitake (new name).

Mycena overholtsii was first described by Alexander H. Smith and Wilhelm Gerhard Solheim in 1953, on the basis of specimens collected in Albany County, Wyoming, USA (Smith and Solheim, 1953). The species name honors the American mycologist Lee Oras Overholts (Evenson, 1997). This species is found growing in clusters on conifer logs and stumps [often Douglas fir (Pseudotsuga menziesii (Mirb.) Franco)] near melting snowbanks, and is a conspicuous part of the spring fungi
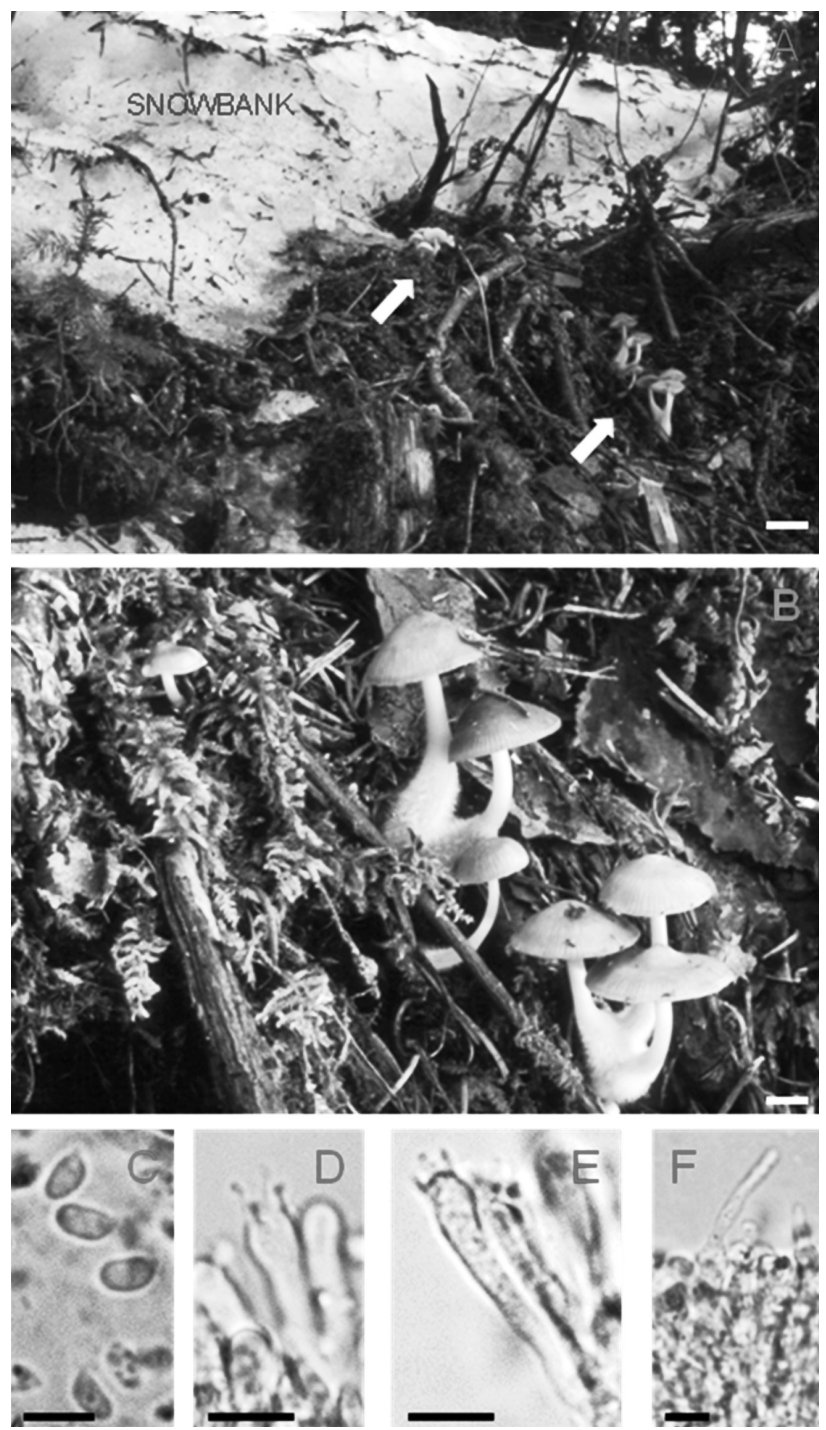

Fig. 1. Mycena overholtsii: basidiomes formed near a snowbank (A, B); basidiospores (C); basidium with four sterigmata (D); basidium (E); cheilocystida (F). Scale bars: $A=40$ $\mathrm{mm} ; \mathrm{B}=10 \mathrm{~mm} ; \mathrm{C}-\mathrm{F}=10 \mu \mathrm{m}$. throughout much of the western mountains in the USA (Miller, 1965; 1985). It is distributed in North America, especially at high elevations in the Rocky Mountains and the Pacific Northwest, where it is fairly common. This species has not been found in Europe or in other continents previously. Mycena overholtsii fruits in clusters on decorticated logs buried in the snow. As snow recedes around the log or stump, the fungi mature in moist snow chambers.

Two of three of our specimens were collected from decaying logs of $A$. sachalinensis and a stump of $P$. jezoensis near a snowbank, and the other was found under the snow chamber formed on a stump in the inner area of a snowbank. The macro- and microscopical features of our specimens are very similar to North American species described by Smith and Solheim (1953) and Miller (1985). In particular, the habitat for fruiting is the same as the North American species associated with snowbanks in spring.

The snowbanks are usually found into forest stands in conifer and mixed forests dominated by conifers, from May to late June in Hokkaido. Although M. overholtsii was first report as a snowbank fungus in this study, some fungi that developed fruit-bodies in early spring and just after snowmelt in Hokkaido should be considered a new group of snowbank fungi from an ecological perspective. Thus, the fungi developing in snowmelt season in Hokkaido will need further investigation to understand their taxonomy and the ecology associated with snowbanks. This is because known snowbank fungi are a taxonomically and ecologically diverse group of flesh fungi, and include both basidiomycetes and ascomycetes adapted to the unique microclimate provided by remnant snow in high-elevation conifer forests in the USA.

\section{ACKNOWLEDGEMENTS}

This study was carried out with the support of 'Forest Science \& Technology Projects (No. S210809L010110)' provided by Korea Forest Service in Korea.

\section{REFERENCES}

Evenson, V. S. 1997 Mushrooms of Colorado and the Southern Rocky Mountains. Westcliffe Publishers: p. 101

Miller, O. K. 1965 Snowbank mushrooms in the Three Sisters Wilderness Area. Mazama 47: 38-41

Miller, O. K. 1985 Mushrooms of North America. E. P. Dutton, New York: p. 367

Miyamoto, T., J. Y. Cha and T. Igarashi 1996 A new record of Mycena picta from Japan. Mycoscience 37: 463-466

Munsell, A. H. 1990 Munsell soil color charts, revised ed. Macbeth Division of Kollmorgen Instruments, Baltimore, Maryland

Smith, A. H. and W. G. Solheim 1953 New and unusual fleshy fungi from Wyoming. Madrono 12(4): 103-109 